\title{
THE ROLE OF THE INTERPERSONAL COMMUNICATION OF CHRISTIANITY TEACHERS IN IMPROVING THE SPIRITUAL GROWTH OF GRADE IX STUDENTS IN SMP NEGERI 2 SIANTAR
}

\author{
BANGUN MUNTE \\ bangunmunte1@gmail.com \\ Universitas HKBP Nomensen Pematang Siantar \\ Erni Murniarti \\ erni.murniarti@uki.ac.id \\ Universitas Kristen Indonesia
}

\begin{abstract}
ABSTRAK
Tujuan penelitian ini adalah untuk melihat sejauhmana Peran Komunikasi Interpersonal Guru PAK dalam meningkatkan pertumbuhan rohani siswa kelas IX di SMP NEGERI 2 SIANTAR. Jumlah sampel sebanyak 53 orang. Penelitian ini menggunakan metode deskriptif, sedangkan analisis data yang dilakukan dalam penelitian hipotesis adalah korelasi product moment pearson dengan alat pengumpulan data adalah angket untuk Variabel $X$ (Peran Komunikasi Interpersonal Guru PAK) dan Variabel Y (Pertumbuhan Rohani Siswa). Untuk mengetahui sejauhmana Peran Komunikasi Interpersonal Guru PAK dalam meningkatkan pertumbuhan rohani siswa, maka digunakan Uji Statistik Korelasi Product Moment Pearson. Dari hasil pengujian diperoleh pengujian korelasi (r) 0,33 dengan uji determinasi sebesar 10.89\% dan untuk mengetahui signifikan tidaknya koefisien korelasi pada taraf nyata $(\alpha)=0,05$ maka diadakan uji " $t$ " dengan kriteria pengujian jika thitung yang didapat dari perhitungan lebih besar (>) dari tabel pada taraf signifikan 1-0,05 dengan dk $=n-2$ maka hipotesis diterima dan dalam hal lain ditolak. Dari hasil pengujian diperoleh $t_{\text {hitung }}>t_{\text {tabel }}(2,49>1,67)$, maka hipotesis diterima. Dengan demikian dapat dikemukakan bahwa terdapat pengaruh yang signifikan dari Peran Komunikasi Interpersonal Guru PAK dalam meningkatkan pertumbuhan rohani siswa di SMP NEGERI 2 SIANTAR
\end{abstract}

Kata Kunci: komunikasi interpersonal, pertumbuhan rohani siswa

\section{ABSTRACT}

The aim of this research is to find out the Role of the Interpersonal Communication of PAK Teacher in improving spiritual growth of Grade IX 
Studnets in SMP Negeri 2 Siantar. The number of samples is 53 students. This research applies descriptive method; meanwhile data analysis used for hypothesis testing is Pearson' product-moment correlation, of which the instruments of data collection are questionnairs for variable $X$ (Role of interpersonal communication of PAK Teacher) and variable $\mathrm{Y}$ (the spiritual growth of students). To examine the Role of the Interpersonal Communication of PAK Teacher in improving spiritual growth, correlation product moment of Pearson was used as the statistical measurement. The data analysis showed that correlation $(r)$ was 0,33 with the determination value at $10.89 \%$; and to know whether the correlation coefficient was significant or insignificant at the level of $(\alpha)=0,05$, t- test was conducted of which the criterion was if $t_{\text {count }}$ got from the measurement was (>)higher than $t_{\text {tabel }}$ at the significant level of $1-0,05$ with $d k=n-2$, the hypothesis was accepted and vice versa. Seen from the result of data analysis, it was found that $t_{\text {count }}>t_{\text {tabel }}(2,49>1,67)$, it meant that the hypothesis was accepted. Therefore, it could be stated that there was a significant effect of the Interpersonal Communication of PAK Teacher in improving spiritual growth at IX class at SMP Negeri 2 Siantar.

Keywords: interpersonal communication, students spiritual growth

\section{INTRODUCTION}

\section{Background of the Study}

Education is an urgent tool to develop human resources and national characters. The dignity of a nation is determined by a quality of its education. In the context of Indonesia, the improvement of the education quality is the aim of the national education development and a part of comprehensive effort to improve the quality of overall Indonesian people. The 1945 Constitution of the Republic of Indonesia, article 31 , paragraph 3 Amendment, states that the government organizes and implements a national education system, to be regulated by law, that aims at enhancing religious and pious feelings as well as moral excellence with a view to upgrade national life.

Since education has an important role for the community life, the government strives to increase the quality of education. In the Regulation number 20/2003, it has been regulated that the aim of the national education is to enlighten the life of the nation and develop Indonesian human being, that is, a human who has faith and devotion to the Almighty God and has virtuous characters, possesses knowledge and skills, physical and 
Munte \& Murniarti, The Role of the Interpersonal Communication of Christianity Teachers in Improving the Spiritual Growth of Grade IX Students in SMP Negeri 2 Siantar

spiritual health, a solid personality, independent, and having societal and national responsibilities.

To gain

the successfulness, the national education should pay attention on the education components especially human resources which has an important role to ensure the successfulness of the school in actualizing the aim of the education. A school is a place where students are guided, coached, taught by a professional teacher. A teacher is one of humane components in teaching and learning process, who plays a role to determine potential human resources for the development of the country. Therefore, as one of the important parts of education, teachers should play an active role as a professional staff, in accordance with the developing society demands.

Communication is also closely related to education. Education is an empowerment process of human capacities as individual and community, which function is not only for empowering the human capacities, but also to develop and control the capacities, so that it is useful for improving the human quality itself. The function of communication in education as a distraction of knowledge can force intellectual development, character building, and forming skills and proficiencies needed in all areas of life. (Widjaja, p. 65).

Interpersonal

communication is one part of supporting communication aspects that is important for life. Interpersonal communication has a role in creating a happy life for human, such as: interpersonal communication helps intellectual and social development; our identity is built by communicating with others. To understand the reality in our surrounding, we need understanding from others.

Interpersonal

communication

happens

anywhere, such as: at home, at school, in society, at office, at church, etc. Within, the interpersonal communication at school, the teacher becomes an important factor. The interpersonal communication between the teacher and students in order to achieve an effective communication, and to increase the growth of student spiritual life, is needed. Since the students sometime tends to do a deviant deeds from the word of God, their spiritual beliefs, especially of a student in junior high school, cannot grow. 
Basically, Christian education must be understood as an education that has an aim and to seriously guide and equip an individual or group to the maturity, especially in terms of ways of thinking, attitude of faith and behaviours. Afterwards, Christian education can be understood for its position as a religion education and teaching - the teaching of the Christian faith. The philosophies, procedures, and missions should be based on the values of Christian faith, as is taught on Bible and church tradition. Christian education is the main procedure of spiritual building that is used by many churches for youth-services as well as at schools. Henceforth, students can strengthen their knowledge better at school.

The rapid growth of current era has a great influence on people's lives, especially Christian teenagers. It is frequently seen and heard in the society that nowadays the norms which become the Christians' life standards-the words of God, are not done or obeyed any longer. The frequent deviation of students' behaviours is brawling among students. Brawling is students' inappropriate behaviour and a form of students' delinquency. Furthermore, the students' politeness is very low at school. In their social life at school, the students often use dirty or taboo words, in consequence it becomes their habit.

There were a lot of cases about juvenile delinquencies done by the students. Based on the data obtained from the counselling teacher, common misconducts done by the students are stealing his/her friends' pens, selling his/her junior's phone, easily being influenced to do wrongdoings, lying to teacher, watching pornographies on the phone--even though phone is forbidden, coming late to school, cheating on tests, ignoring a chance to lead the pray-when it comes to prayer, some students remained having chitchat and laughing, lack of understanding about Congregation Songs, even how to open Bible, some students often call their friends' parent names without knowing that it is impolite and disobey of the words of God, namely the fifth Commandment, the students feel happy when their parents' names are called out, brawl between or among students, lack of politeness in speaking, skipping from school (jumping over a fence), wearing incomplete uniform, wearing inappropriate clothes, and mocking their teachers by giving a certain epithet. 
Munte \& Murniarti, The Role of the Interpersonal Communication of Christianity Teachers in Improving the Spiritual Growth of Grade IX Students in SMP Negeri 2 Siantar

The growth of spiritual life is impossible to be achieved through self-effort or by considering it as private issue. The growth of spiritual life needs a relation with others to be able to grow. In relation to the students' spiritual growth at school, Christianity teachers are the most related ones to this, and become the most appropriate ones to endeavour the students' spiritual lives. In this case, Christianity teacher should have a good interpersonal communication skill in the process of teaching and learning.

Interpersonal

communication between the teacher and students should be conducted reciprocally and alternately; it can be started from the teacher to the student or vice versa. The beginning of communication is because there is a message to be conveyed, so that an effective communication between both sides occurs. This communication is considered effective to change attitudes, opinions, or behaviours of someone because the nature is dialogical, face to face, and interactive, so that a personal contact occurs (Effendy, 2002, h.8). Therefore those who are involved in this communication become a speaker and a listener.
In this situation, a mutual respect exists based on the assumption that each of them is a human who obliges, entitles, and deserves to be appreciated and respected as human being. Through interpersonal communication, the teacher learns how and to what extent a teacher should open up, positively behave, and have empathy to the students, in the context of the teacher telling about his/her life record to students, so that the students can imitate the teacher's positive behaviours or attitudes. Christianity teacher is able to realize his/her position as an evangelist, who is responsible for the students' surrenders to Jesus Christ. It is not enough if she/he just conveys to them everything about Christ. The aim of the teaching is to make them become Jesus Christ's students who are diligent and loyal. The teacher should not be satisfied before his/her student become a true Christian.

\section{THEORITICAL REVIEW}

Interpersonal

communication is a face-to-face communication among people which allows each participant to acknowledge the reaction of others directly, verbally, as well as nonverbally (Mulyana, 2004, h.73). 
Devito (as cited in Effendy, 2003, h.59) says that the definition of interpersonal communication is a process of sending and accepting messages between two people, or among a small group of people, with instant feedbacks.

In a journal entitled "Acta Diurna" Vol 1, No. 1, year 2013, there is mentioned that interpersonal communication is essentially one form of personal communication. Interpersonal communication is a face-to-face communication among people that allows each participant to acknowledge the reaction of others directly, verbally as well as nonverbally. Interpersonal communication is potential to be run as an instrumental function, namely as a tool to influence or persuade others, because we can use our five senses to strengthen the persuasion message that we communicate to our communicant. Becoming the most complete and perfect communication, interpersonal communication plays an important role every time, as long as human is still having an emotion. In reality, face to face communication makes human feels more familiar with others; it is different from the communication through mass media like newspaper, television, or even advanced technologies (Mulyana, 2005, h. 73).

Hardjaja (as cited in Suranto Aw, 2011, h.3) states that interpersonal communication is face to face interaction between two or more people, where the sender can deliver the message directly. Furthermore, Cangara (2011, h.32) affirms that, seen from its nature, interpersonal communication is divided into two kinds: dyadic communication and small group communication. Dyadic communication is a face-toface communication process between two people which can be done in 3 forms i.e. conversation, dialogue, and interview. Small group communication is a face to face communication process among three people or more, whose members are interacting one to another.

Eight aspects which become the characteristics of interpersonal communication characteristic are as following:

- Interpersonal communication happens spontaneously. It means interpersonal communication usually happens coincidentally without any plan, so that the 
Munte \& Murniarti, The Role of the Interpersonal Communication of Christianity Teachers in Improving the Spiritual Growth of Grade IX Students in SMP Negeri 2 Siantar

conversation

happens

spontaneously.

- Interpersonal

communication is

associated with a

goal-setting problem.

- Interpersonal

communication is

accidental and

participant's identity.

Through

interpersonal

conversation,

relationship and

someone's identity

can be known.

- Interpersonal

communication is a

form of a

consequence. What

is meant by the

consequence is the

results

of

conversation of the

interpersonal

communication.

Interpersonal

communication has

intentional and

accidental

consequences.

- The nature of interpersonal communication is reciprocal. One of the interpersonal communication

characteristics is

mutual responses,

giving and taking information between the communicator and the communicant alternately, so that the dialogic atmosphere takes place.

- Interpersonal

communication is associated with the amount of people, atmosphere and impacts. People like to communicate with others, because each of them tries to get closer to each another.

- Interpersonal communication is related to results. It is categorized success if the communication itself generates something to expect and tangible results. It is tangible in changing insight, feelings and also behaviours.

- Interpersonal communication is a message 
significant symbols.

The process of communication always sends a message. (Liliweri, 1997, h.14)

Furthermore, Widjaja (2000, h.122) says that there are some interpersonal communication goals which are considerable to be adopted, as follows:

1. Get to know yourself and others.

One way to know yourself is through interpersonal communication. Interpersonal communication gives a chance for us to talk about ourselves. By communicating about ourselves to others, we can get a new perspective about ourselves and further understanding about our behaviours and attitudes.

2. Discover the outside world Interpersonal communication allows us to understand our surroundings better, such as objects, phenomena, and others. We have a lot of information because of interpersonal communication.
3. Create and maintain relationship

Human is created as a social being, so that in daily life people want to create and maintain a close relation with others.

4. Change attitude and behaviour

In interpersonal communication, we often try to use other's attitude and behaviour. The desires choose a kind of ways, try new food, read a book, think in a certain way, and others. Simply, there are many ways to persuade others through interpersonal communication.

5. Play and Have fun

Playing includes all activities to get pleasure. Other similar talks are activities aimed at obtaining entertainment.

6. Help other

We often give an advice and suggestion to friends who have a hard time and try to solve it. It shows that the aim of interpersonal communication process is to help others.

In the journal of 'Dwiny Yusnita Sari', there is said that by building relationship through interpersonal communication, someone can get along with other, and indirectly also have a benefit for his/her personal life, since the communication reveals ideas, feelings, 
Munte \& Murniarti, The Role of the Interpersonal Communication of Christianity Teachers in Improving the Spiritual Growth of Grade IX Students in SMP Negeri 2 Siantar

thoughts and self-behaviours (Bimo, 2001).

Cangara (2003) mentions that there are some functions of interpersonal communication, as follows :

1. Intensify human relation

2. Avoid and solve self-conflict

3. Decrease an uncertain thing

4. Share knowledge and experience with others

5. Capable to improve humanitarian relations between parties who communicate

6. Obtain a convenience in social life

7. Capable to foster good relationships and avoid conflicts with others.

Communication is the foundation of interaction among people, because without communication, human interactions-individual, group or organization, are impossible to take place. Interpersonal communication is a process of sending and receiving message between two people or among a small group of people, with various effects and feedbacks. The beginning of communication is because there is a message to deliver, so that both parties create an effective communication.
According to De Vito (as cited in Widjaja, 2000) the effectiveness of interpersonal communication from the humanistic perspective, which become the indicators if this research are:

\section{A. Openness}

Self-openness is a kind of communication where we deliver information about ourselves that usually we keep as a secret (Devito, 1997). Johnson (1993, h.25) says that self-openness is the expression of reaction or our response toward the current situation and giving a relevant information about past life or something that is useful to understand our current responses. There are some characteristics about self-openness, such as: a function of ongoing relationship, done by both parties, adapted to ongoing situation, related with what is happening today and among people involved, and there is an enhancement of attitude, slowly (Mulayan, 2007:36).

There are six aspects of self-openness, such as: be objective, be provisional, understand yourself, understand others, apply trust, and adopt an open attitude (Johnson, 1993, h.30). In communication a person cannot directly express his/her feeling. To be able to express the 
problem or information, the relationship between individual should be familiar and open. The more open an individual wants to talk about something, the deeper communication level takes place.

Openness is an attitude that can accept others' opinions, and be pleased to deliver an important information to others. through openness, the interpersonal communication may happen fairly, transparently, two-way direction, and acceptable for everyone involved. The benefit of selfopenness in communication is to make an individual be able to deliver his/her self-information, e.g. life experiences, feeling, emotion, opinion, dream, attitude, behaviour, desire, motivation, ideas, etc. The information delivered can create a deep and meaningful relationship so it can improve understanding about oneself and others. By expressing oneself to others, individuals feel valued, cared for, and trusted by others, so that the communication relationship will become more familiar.

The quality of openness refers to two aspects in interpersonal communication at least. First, as an interpersonal communicator, a Christianity teacher should be opened to the students with whom he or she interact. It doesn't mean the Christianity teacher should open all of the life record as soon as possible. It is interesting but it usually does not help communication. Otherwise, there should be a willingness to open up hidden but needed information.

The second aspect of openness refers to the willingness of Christianity teacher as a communicator to react honestly toward the coming stimulus. A quiet, uncritical and unresponsive person is usually a drab participant in conversation. We want others to openly react of what we are talking. And we deserve to expect this. There is nothing worse than being ignored, even a disagreement is better. We show openness through the way of react spontaneously to others.

Openness is a desire of people to tell an information about themselves which might be normally hidden; it should be a right statement (Devito, 2007, h.112). Openness is also a desire to listen openly and react honestly to others' messages. To have an openness, a person should:

- Open themselves at right time

- Response to others who interact with us spontaneously and 
Munte \& Murniarti, The Role of the Interpersonal Communication of Christianity Teachers in Improving the Spiritual Growth of Grade IX Students in SMP Negeri 2 Siantar

honestly and also with awareness of our words and of the impacts of our messages.

- Have a thought, feeling, and responsibility of what we have delivered.

The function of communication in the relationship with others is that we can get to know others through selfopenness, exchange ideas, asking for helps, and helping each other to change a behaviour and attitude (Bimo, 2001, h.67).

\section{B. Positiveness}

Positiveness is shown in the form of attitude and behaviour. In the form of attitude means that the parties which are involved in interpersonal communication should have a positive feeling and mind, not a prejudice and a suspicion. In the form of behaviour, means that the chosen action is relevant with the aim of interpersonal communication that is doing an actual activity to establish cooperation.

We communicate a positiveness in interpersonal communication with at least two ways: 1.) declare a positive attitude and 2.) positively encourage our friends to interact.
A positiveness is a tendency of someone to do something, based on a good judgment without having excessive guilt feeling, receive oneself as an important and valuable person to others, have a confidence in their ability to overcome problems, be sensitive to the needs of others and to social habits that have been accepted, be able to give and receive praise without pretending to give and receive awards without a guilty feeling. Sugiyo (2005, h.6) says that a positiveness is a tendency of communicator to give a positive judgement to the communicant. In interpersonal communication, both communicators and communicants should show each other a positive attitude, because in this communication relationship will appear pleasant atmosphere, so that the termination of communication won't take place. A positive perspective and feeling about oneself will result in positive patterns of interpersonal communication behaviours.

A positiveness can be shown in various attitudes and behaviours, such as:

- Respecting other

- Positive thinking to other

- Having no excessive suspicion 
- Believing in the importance of others

- Giving a praise and appreciation

- A commitment to establish corporation

\section{Empathy}

One form of communication for someone to successfully interact with others is empathy. Empathy forces an individual to change mindset, from rigid to flexible, from selfish to tolerant. Empathy is an ability with a combination of affective cognitive dimensions, leaving no realm of behaviour that makes these abilities real. Personal responsibility for doing something for other individuals, will function effectively if it is manifested in the form of behaviour. A combination in empathy will help the individual to be right and proportional to see the problem at hand.

Empathy is to feel what others feel from someone's point of view without losing our identity (De Vito, 2007, p. 248). Empathy enables us to understand what other people are emotionally.

Rogers and Bhownik (as cited in Effendy, 2003, h.69) define empathy as a person's ability to project himself to the role of others. Empathy is a person's ability to put himself in the role or position of others. In a sense, that someone is emotionally and intellectually able to understand what others feel and experience. In empathy we assume ourselves as other people, who must be able to feel the suffering or pleasure experienced by that person, without losing our identity. The three characteristics of empathy are:

1. Listen carefully to what others tell, how they feel, what happens to them,

2. Arrange appropriate words to describe the person's feelings and situation,

3. Use the arranged words to recognize others and try to understand their feelings and situation.

Daniel Goleman (1997, h. 158) proposed three characteristics of empathy, as follows:

1. Listening to other people's conversations well, meaning that individuals are able to give attention and be a good listener of all the problems expressed by others to him.

2. Accepting the point of view of others, meaning that individuals are able to see the problem from the point of view of others so that it will lead to tolerance and the ability to accept differences. 
Munte \& Murniarti, The Role of the Interpersonal Communication of Christianity Teachers in Improving the Spiritual Growth of Grade IX Students in SMP Negeri 2 Siantar

3. Sensitive to other people's feelings, meaning that individuals are able to read other people's feelings from verbal and non-verbal cues such as speech, facial expressions, gestures and other body language.

According to Timpe (1999, hh. 283-284) in the journal "Cakrawalla Pendidikan, Februari 2003, Th, XXII, No.1 page 53, there are three methods that can be used to change the sensitivity of feelings so that one's empathy increases.

a. Introspection and using trusted friends as a place of self-reflection.

b. Seeking help from the professional people,

c. Interacting with groups that attended feeling sensitivity training.

Empathy can be interpreted as exploring others' feeling, but still maintaining separation involvement. Empathy means being able to enjoy what others feel, without losing identity. For this reason, it is necessary to be able to respond appropriately to the needs of others, without being influenced by it. An empathetic person can feel the pain of other people's feelings but not get hurt by his feelings. He can feel: confusion, anger, fear, or someone else's love as if these things happen to his own feelings, but he does not lose consciousness that it is only "as if".

According to Siregar (2009, h. 63) there are three steps that we must take or live faithfully so that our spiritual life grows, as follows:

\section{Prayer}

Prayer is spiritual breath for all believers. Prayer described as ladder to reach heaven. Jesus Christ taught His disciples to pray (Matthew 6:5-15) and told them to pray and not lose heart (Luke 18:1; 22:40). God is the principle role play for us in prayer. God lives in close fellowship with his Father in heaven showed by through life in prayer. Paul suggested that: continue steadfastly in prayer (1 Thessalonians 5:17; Colossian 4:2). The Apostles and the first congregation also realized how important prayer is in their lives and ministry ( Kis 2:42; 9:40; $13: 3 ; 16 ; 25)$. Prayer is human greatest need, the secret of failure is because the failure in prayer. Prayer is the most important key to win spiritual awakening and ministry development ( Ef 6 18-20).

Prayer is open your heart to the merciful God. We are the children of God and our Father is 
God "But to all who receive him, who believes in his name, he gave the right to become the sons of God". (John 1:12)

Prayer is to present your plea and praise to God. Pray to God means hope and beg to him as the communication to hear the voice of the Lord our God. Prayer is the breath of lives for believers.

According to Santoso and Kuswandi ( Memulai hidup baru, 2005:18-19), the contents of prayer are, as following:

1. Worship

2. Thankfulness

3. Recognition of sins

4. Prayer for ourselves and others.

And when you pray, must not be like the hypocrites. They like to say their prayers by standing in houses of worship and on the corners of the highway. So that they are seen by people. Surely they have got their reward. But when you pray enter your room, close the door and pray to your Father who is in a hidden place. Then your Father who sees the hidden will repay you. For they love to stand and pray synagogues and at the street corners, that they may be seen by others. Truly they have received their reward. But when you pray, go into your room and shut the door and pray to your
Father who is in secret. And your Father who sees in secret will reward you. And when you pray, do not heap up empty phrases as the Gentiles do, for they think that they will be heard for their many words. Do not be like them, for your Father knows what you need before you ask him (Matthew 6:68).

Prayer is a privilege for the sons of God to draw near to the presence of God. For the spirits we cry to God: "Abba! Father!" (Romans 8:15). Reading and dwell in the word of God make us more mature, strong and spiritually fruitful, and increasingly reflect the life of Christ.

M. Siregar (2009:80) explained prayer guidelines as following:

a. We have to pray in Jesus name ( John 4:13-14, 16:24)

b. Ask in faith with no doubting (James 1:6)

c. Ask with all your heart and don't be doubt (Proverb 119:58)

d. Pray according to the will of our God in heaven.

\section{The Word of God}

The word of God is always called as spiritual food, because through the word of God our spiritual lives becomes alive, 
Munte \& Murniarti, The Role of the Interpersonal Communication of Christianity Teachers in Improving the Spiritual Growth of Grade IX Students in SMP Negeri 2 Siantar

growing and strong. God revealed all His will to humans through the Bible. Everything is important in this world, so that every Christians must try to read the entire of Bible. Making a plan to read the entire Bible at a certain time is helpful. If we read three or four chapters every day we can read all the contents of the Bible in one year. We can understand or read the entire Bible one time in four years if we take part in Church service activities, we must read the Bible more often.

Reading the Bible can be started from Genesis then another one till arrived at book of Revelation. Man shall consist of body and spirit (soul). Therefore, in order to have healthy life we need to eat and drink every day with sufficient and nutritious amounts, as well as our soul and spirit. To be able to live and develop, we need to eat. Spiritual food is the word of God. It is said that "For mankind lives not by bread alone, but by every word that comes out of the mouth of God (Matt: 4: 4). Bread is physical food while God's Word is spiritual food.

The Bible contains God's statement about Himself or His person, about His power, His glory, His attributes and also about His great deeds, the creation of a world with all its contents, including humans, His care for His creation. The Bible also contains statements about salvation that God planned and provided in Christ. In the Bible, there is also written promises or guarantees from God, those are a guide for us, to encourage us to worship Him, repent and believe (Proverb 103). Through the Bible God manifested his throne and his rules over all for us to obey.

\section{Fellowship}

The fellowship of believers has been described as a function of warm clothing, which gives warmth to the body. Without warm clothes, the body feels cold. Likewise, with fellowship, without fellowship with fellow brothers in Christ, our spiritual life feels cold. Through fellowship our spiritual life can grow and our faith is encouraged. Therefore the alliance is very important, because through it we can support one another, warm each other and build on each other. In fellowship we can worship together, grow together, serve together and help each other.

Since the beginning God delights for man lives in fellowship (Genesis 2:18; Ecclesiastes 4:910). Through the fellowship we can shore up one to another in love that the world may believe that 
God have sent you through the fellowship (John 17:21b). The importance of fellowship of believers to make strengthen and multiply the spiritual life or faith, for the advancement and expansion of God's kingdom in this world and the highest goal is for God's glory.

According to $M$. Siregar (2009:94), in New Testaments there are some advices to build and maintain the fellowship of believers, namely:

a. Believers are advised to accept one another. (Romans 15:7)

b. Stronger people are willing to yield, accept, and bear weakness that is not strong for their good, and to build it (Romans 14:1; 15:1). We are advised to sympathize or to share with our neighbor's pleasures and troubles (1 Corinthians 12:26; Romans 12:15)

c. One condition for maintaining fellowship is to walk in the light (1 John 1:7)

d. Don't be selfish or just pay attention to the interests of himself or his group alone (Phi 2:4)

e. Live humbly (Phi 2:3; 5-8)

f. Believers are called to maintain that fellowship by distancing attitudes which are coupled with negative interrelationships, as in several Scriptures, we are advised to practice our positive keys, such as Mutual love (Rom 12:10;138; 1 John 1:11).

\section{Research Methodology}

This research method is closely related to the method used in the study. The method used is descriptive research method that is deliberately designed to analyze the data and determine the relationship of the independent variable $(X)$ on the dependent variable $(\mathrm{Y})$, then draw conclusions about the data collected and analyzed. Quantitative Descriptive Research Method is a method in examining a case of a group of people, a system of thought, or a class of events in the present time that aims to make a description, systematic explanations factually and accurately about facts, characteristics and relationships between phenomena investigated. In line with what was stated by Furchan (1982, p. 53), the descriptive method is to describe and interpret the current situation and agree with the conditions or relationships that exist, current practices, particular views or attitudes, ongoing processes, 
Munte \& Murniarti, The Role of the Interpersonal Communication of Christianity Teachers in Improving the Spiritual Growth of Grade IX Students in SMP Negeri 2 Siantar

suggested effects or developing trends.

Accordingly, Surahman (1972:32) stated that descriptive methods are research methods aimed at solving problems that exist in the present and solving actual problems. Sumarni (2012: 106) also said that "Quantitative Research is a process of finding data in the form of numbers as a tool to find information about what we want to know". Quantitative research also can be in the form of correlation research, quasiexperimental research, and experimental research. Then clearly seen descriptive quantitative research method is a method of research to obtain data on the current situation.

In this research, the study population were grade IX students of SMP Negeri 2 Siantar especially those who are Christians. Based on preliminary studies obtained data as many as 122 students. Which consisted of 63 boys and 59 girls. The details can be seen from the table below. To determine the size of the sample, the researcher used the Cochran's formula. Based on the calculations above, the number of samples was 53 .

\section{RESEARCH DISCUSSION}

Data analysis used in this study is statistics. Statistics in quantitative research are categorized into two, namely: descriptive statistics and inferential statistics. Descriptive statistics is an analysis that describes more clearly the data presented. Descriptive statistics is an analysis that describes more clearly the data presented. Presentation of this data is usually done with tables and graphs, measures of central tendency, and measures of data variables. Inferential Statistics is to explain findings that can make a generalization of a larger population. One important part of inferential statistics is hypothesis testing. The hypothesis of this research was: the null hypothesis $\left(\mathrm{H}_{0}\right)$ which is a statement that shows similarity. As the opposite is the alternative hypothesis or working hypothesis $(\mathrm{Ha})$ which are shows the difference.

\section{Data Analysis about the Role of Interpersonal Communication of Christianity Teachers in in Improving Students' Spiritual Growth}

\section{a. Generally}

Based on the results of data analysis obtained from the study (SMP Negeri 2 Siantar) it was 
found that the interpersonal communication of Christianity Teachers plays a role in increasing students' spiritual growth.

\section{b. Particularly}

\section{Openness}

Based on the results of data analysis obtained from the study, openness-if the results were included in the assessment criteria, has a significant influence in increasing students' spiritual growth.

\section{Positive Behavior}

Based on the results of data analysis obtained from the study, positive behavior-if the results were included in the assessment criteria, has a significant influence in increasing students' spiritual growth.

\section{Empathy}

Based on the results of data analysis obtained from the study, empathy-if the results were included in the assessment criteria, has a significant influence in increasing students' spiritual growth.

\section{Data Analysis about Student Spiritual Development}

Based on the results of data analysis about the student spiritual development-if the results are included in the assessment criteria, it can be stated that the Interpersonal Communication of Christianity Teachers has a significant influence in improving students' spiritual development in SMP Negeri 2 Siantar.

\section{Research Findings}

Based on the results of data calculation and hypothesis testing, hence the results of the research findings can be stated as follows:

1. After conducting the normality test of data on data $X$ and $Y$ as one of the requirements before executing hypothesis testing, it turned out that data $X$ and $Y$ are normally distributed. The normality testing was done by using the Chisquare formula $\left(\mathrm{X}^{2}\right)$ table with the sig. $\alpha=0.05$, namely:

a. Data $X$ (The role of Christianity Teachers' Interpersonal Communication) $X^{2}$ count $=$ 102.63 while $X^{2}$ table $=12.6$. It means that the data $X$ (The role of Christianity Teachers' Interpersonal Communication) is in a 
Munte \& Murniarti, The Role of the Interpersonal Communication of Christianity Teachers in Improving the Spiritual Growth of Grade IX Students in SMP Negeri 2 Siantar

normal distribution or data

$X$ comes from a normally distributed sample.

b. Data Y (Student Spiritual Growth) $\quad Y^{2}$ count $=-98,719$ while $\mathrm{Y}^{2}{ }_{\text {table }}=12.6$, meaning that data $Y$ (Student Spiritual Growth) is in a normal distribution or $\mathrm{Y}$ data comes from a normally distributed sample

2. Data Analysis of Hypotheses Testing

a. Correlation Coefficient

The results obtained from the correlation coefficient are 0.33 ; it means that the role of interpersonal communication has a positive correlation in improving students' spiritual development, then the hypothesis is accepted.

b. Correlation Significant Test

After the calculation is obtained the value of $t_{\text {count }}$ $=2.49>t_{\text {table }}=1.67$; it indicates that there is a significant relationship of Christianity Teachers' Interpersonal

Communication in improving student spiritual development. c. Determination Coefficient Test

Christianity Teachers' Interpersonal

Communication has $10.89 \%$ influences in improving students' spiritual development. This contribution was seen from the determination coefficient $r^{2}=0.332 .100 \%$ $=10.89 \%$; it signifies that the higher the integrity of variable $X$, the higher the effect on variable $Y$.

d. Simple Linear Regression Based on the data analysis, it was obtained that the relationship between variables $X$ and $Y$ could expressed in the form of regression equation, namely $Y=1.01$ $+0.61 X$, it means that every increase in unit $X$ influences $Y$ by 0.61 . In other words, if Christianity Teachers' Interpersonal Communication plays a better role, the higher results obtained in the Students' Spiritual Growth. e. Independent Sample TTest

After calculation, it is obtained that $F_{\text {count }}=0.11<$ $F_{\text {table }}=0.96$, it means that 
variable $Y$ is linearly independent of variable $X$.

f. Regression Equation of Variable $X$ and $Y$ is Linear Model

Based on the data obtained from the field (see appendix), the Role of Christianity Teachers' Interpersonal Communication (Variable X) were divided into 3 indicators, namely:

1. Openness, discussed in appendix 4 table 4.3 , shows the results of 2.668 , which means the openness possessed by Christianity teachers has a significant relationship in improving the students' spiritual growth that the hypothesis was accepted.

2. Positive Behavior, discussed in appendix 4 table 4.4 , shows the results of 2,737 , which means that the positive behavior of Christianity teachers has a significant relationship in improving the students' spiritual growth that the hypothesis was accepted.

3. Empathy, discussed in appendix 4 table 4.5 , shows the results of 2.74; it means that the Empathy of Christianity teachers has a significant relationship in improving the students' spiritual growth that the hypothesis was accepted.

\section{CONCLUSION AND SUGGESTION \\ Conclusion}

This research emphasized on the role of the Christianity teachers' interpersonal communication in improving the students' spiritual growth. This can be seen from the calculation of the correlation coefficient, significant correlation test, determination test, simple linear regression test, independent sample t-test and regression linearity test. Specifically, the result of the research showed that the role of Christianity teachers' interpersonal communication had a positive impact toward the students' spiritual growth seen from several aspects, namely:

a. Openness had a positive impact toward the students' spiritual development.

b. Positive behavior had a positive impact toward the students' spiritual development.

c. Empathy had a positive impact toward the students' spiritual development. 
Munte \& Murniarti, The Role of the Interpersonal Communication of Christianity Teachers in Improving the Spiritual Growth of Grade IX Students in SMP Negeri 2 Siantar

\section{Suggestion}

\begin{abstract}
Based on previous discussion, it is known that this research had successfully answered the research question. However, the research needs to be developed and studied further. There are some suggestions offered, as follows:
\end{abstract}

a. Christianity teachers should improve and focus on carrying out the teachings and God's will in acts as well as in words. The devotional line, as a guidance for Christianity teachers in educating students is Romans 2: 19-24, "and believe that you are the guide of the blind and the light of those who are in the dark, the educator of the fool, and the teacher of the immature, because in the law you have the fulness of all intelligence and truth.

b. The Christian students of SMP Negeri 2 Siantar should develop themselves in accordance with the character of Jesus, in order to increase their spiritual growth. Therefore, the hope of being the best junior high school in Simalungun Regency can be realized.

\section{REFERENCES}

Abdul dan Mustaqim. (2003). Psikologi pendidikan. Jakarta: Rineka Cipta.

Arikunto, S.. (2013). Prosedur penelitian. Jakarta: Bina Aksara.

Belendina, J . (2005). Professionalisme guru dan bingkai materi. -: Bina Media Informasi.

Boehkle, R. R. (1996). Sejarah perkembangan pikiran dan praktek pendidikan Agama Kristen. Jakarta: BPK Gunung Mulia.

Sidjabat, B.S. (2009).Mengajar secara profesional, Bandung: Yayasan Kalam hidup, 2009

Cangara, H.. (2005). Pengantar ilmu komunikasi. Jakarta: PT Raja Grafindo Persada.

Cully, I. (2006). Dinamika pendidikan Kristen. Jakarta: BPK Gunung Mulia.

Djaali, H. (2006). Psikologi pendidikan. Jakarta: Rineka Cipta.

Dalyono, M. (2009). Psikologi pendidikan. Jakarta: Rineka Cipta.

Djamarah, B. S.. (2000). Guru dan anak didik dalam interaksi 
edukatif. Jakarta: Rineka Cipta.

Enklaar dan Homrighausen. (2004). Pendidikan Agama Kristen. Jakarta: BPK Gunung Mulia.

Ismail, Andar. (2004). Ajarlah mereka melakukan. Jakarta: BPK Gunung Mulia.

Lembaga Alkitab Indonesia, (2005). Alkitab. Jakarta.

Mulyana, D. (2000). IImu komunikan sebagai pengantar. Bandung: PT Remaja Rosdakarya

Nainggolan, J.. (2006). Menjadi guru Agama Kristen (suatu upaya peningkatan mutu dan kualitas profesi keguruan). Bandung: Generasi Info Media.

Purwanto, N. M. (1990). Psikologi pendidikan. Bandung: PT Remaja Rosdakarya.

Poerwadarminta, W. J. S. (1996). Kamus besar Bahasa
Indonesia. Jakarta: BPK Gunung Mulia.

Rahmat, J. (2007). Psikologi komunikasi. Bandung: PT Remaja Rosdakarya.

Siahaan, SM. (2015). Komunikasi pemahaman dan penerapannya. Jakarta: BPK Gunung Mulia.

Slameto, (2003). Belajar dan faktor-faktor yang mempengaruhinya. Jakarta: Rineka Cipta.

Sukardi, D. K. (1994). Bimbingan dan penyuluhan di sekolah. Surabaya: Usaha Nasional. Sudjana. (2002). Metode statistika. Bandung: Tarsito.

Sugyono. (2013). Metode penelitian kuantitatif dan kualitatif. Bandung: Alfabeta.

Uchjana, E. O. (2003). IImu, teori dan filsafat komunikasi. Bandung: PT Citra Aditya Bakti.

Widjaja. (2000). Psikologi komunikasi. Jakarta: Rineka Cipta. 